\title{
Kesalahan Jawaban Siswa SMA berdasarkan Newman Ditinjau dari Tingkat Kecemasan Matematis
}

\author{
Ati Suhaeti*, Neneng Aminah, Ika Wahyuni \\ Pendidikan Matematika, Universitas Swadaya Gunung Jati, Cirebon, Indonesia \\ *Coresponding Author: suhaetiati02@gmail.com \\ Dikirim: 06-10-2021; Direvisi: 15-10-2021; Diterima: 16-10-2021
}

\begin{abstract}
Abstrak: Penelitian ini bertujuan untuk mengetahui jenis kesalahan yang dilakukan siswa SMA berdasarkan NEA ditinjau dari tingkat kecemasan matematis siswa. Metode penelitian yang digunakan adalah kualitatif dengan jenis penelitian study kasus (case study). Subjek penelitian ini yaitu kelas XI MIPA 1 SMAN 1 Luragung sebanyak 5 siswa yang dipilih berdasarkan pertimbangan tertentu (purposive sampling). Teknik pengumpulan data yang digunakan yaitu angket kecemasan matematis, soal tes, dan wawancara. Hasil menunjukkan bahwa siswa dengan tidak ada kecemasan matematis melakukan kesalahan memahami (comprehension error), dan kesalahan menuliskan jawaban akhir (encoding). Siswa dengan kecemasan matematis ringan melakukan kesalahan memahami (comprehension), dan kesalahan menuliskan jawaban akhir (encoding). Siswa dengan kecemasan matematis sedang melakukan kesalahan membaca (reading error), kesalahan transformasi (transformation error), kesalahan ketrampilan proses (process skill error), dan kesalahan menuliskan jawaban akhir (encoding). Siswa dengan kecemasan matematis berat melakukan kesalahan memahami (comprehension), kesalahan proses (process skill error), dan kesalahan menuliskan jawaban akhir (encoding). Siswa dengan kecemasan matematis berat sekali melakukan kesalahan membaca (reading error), kesalahan memahami (comprehension), kesalahan transformasi (transformation error), kesalahan ketrampilan proses (process skill error), dan kesalahan menuliskan jawaban akhir (encoding).
\end{abstract}

Kata Kunci: Kesalahan; Newman; Kecemasan

Abstract: The study aimed to find out the types of mistakes high school students make based on the NEA reviewed from the student's mathematical anxiety level. The research method used is qualitative with the type of case study. The subject of this study is class XI MIPA 1 SMAN 1 Luragung as many as 5 students selected based on certain considerations (purposive sampling). The data collection techniques used are mathematical anxiety questionnaires, test problems, and interviews. The results showed that students with no mathematical anxiety made comprehension errors, and encoding errors. Students with mild mathematical anxiety made comprehension errors, and encoding errors. Students with moderate mathematical anxiety are making reading errors, transformation errors, process skill errors, and encoding errors. Students with severe mathematical anxiety make errors in comprehension, process skill errors, and encoding errors. Students with heavy mathematical anxiety make reading errors, comprehension errors, transformation errors, process skill errors, and encoding errors.

Keywords: Mistakes, Newman, Anxiety

\section{PENDAHULUAN}

Setiap orang memerlukan pendidikan. Pendidikan merupakan salah satu usaha manusia untuk menambah ilmu pengetahuan sehingga pendidikan diberikan sejak kecil baik pendidikan secara informal, nonformal maupun formal. Mengapa 
demikian? Pendidikan memegang peranan yang sangat penting didalam kehidupan manusia. Dengan adanya pendidikan manusia menjadi berkembang dan memiliki banyak pengetahuan sehingga dapat bersaing secara global. Salah satu bidang ilmu yang penting dan harus ada didalam suatu pendidikan adalah matematika.

Matematika merupakan salah satu cabang ilmu pengetahuan yang mempunyai peranan penting dalam perkembangan ilmu pengetahuan dan teknologi, baik sebagai alat bantu dalam penerapan-penerapan bidang ilmu lain maupun dalam pengembangan matematika itu sendiri (Siagian, 2016). Ardiawan (2015) juga mengatakan bahwa matematika dikatakan penting yaitu sebagai wahana pendidikan tidak hanya digunakan untuk mencapai tujuan, seperti mencerdaskan anak bangsa tetapi juga untuk mempersiapkan mahasiswa agar dapat menghadapi perubahan keadaan di dalam kehidupan.

Didalam matematika banyak ilmu-ilmu dasar seperti mengenal jenis-jenis bilangan, himpunan, aljabar hingga trigonometri. Pada penelitian kali ini peneliti akan membahas materi tentang trigonometri.. Mengapa materi trigonometri penting untuk dipelajari? Karena pemanfaatan ilmu trigonometri banyak digunakan dalam kehidupan sehari-hari seperti menentukan gradient tertinggi dari suatu tanjalan dijalan umum di pegunungan agar semua kendaraan dapat melewatinya dengan aman, mengukur luas atau keliling tanah, dan menghitung berapa "lift force" suatu sayap profil pesawat dengan kecepatan tertentu yang tidak boleh dilewati.

Menurut Kaliky (2017) materi trigonometri merupakan salah satu mata pelajaran yang dianggap sulit oleh siswa, kesulitan siswa diantaranya adalah mengenai sudut-sudut berelasi maupun identitas trigonometri, dimana kebanyakan siswa belum mampu melakukan pembuktian identitas trigonometri. Kesulitan yang dihadapi oleh siswa, dapat menjadi hambatan dan penyebab siswa dapat melakukan kesalahan dalam memecahkan masalah yang diberikan.

Berdasarkan hasil Penilaian Akhir Semester tahun 2020/2021 di kelas XI MIPA1 SMAN 1 Luragung dari 35 siswa 20 siswa memperoleh nilai lebih dari KKM yang ditetapkan yaitu 66 dan 15 orang siswa mendapatkan nilai kurang dari KKM, artinya masih ada siswa yang menjawab salah.

Migon (Mohyuddin \& Khalil, 2016) menyatakan bahwa seseorang memilih yang salah sebagai kebenaran maka sebuah kesalahan akan terjadi. Bila prosedur yang diadopsi berbeda dari prosedur yang diterima (tindakan yang keliru); Bila hasil sebenarnya berbeda dari tujuan (hasil yang keliru); konsep yang keliru mungkin mengahasilkan hasil yang tidak rasional dan menghalangi pemecahan masalah. Mulyono (2009) menyatakan bahwa terdapat beberapa kesalahan umum yang dilakukan siswa dalam menyelesaikan tugas-tugas dalam bidang studi matematika yaitu tulisan yang tidak dapat dibaca, kekurangpahaman tentang simbol-simbol, dan nilai tempat perhitungan penggunaan proses yang keliru.

Kesulitan siswa dalam mengerjakan soal yang diberikan juga merupakan sebuah penyebab kesalahan yang dilakukan siswa. Irawan (2012) menyatakan kesalahan-kesalahan dapat disebabkan karena siswa tidak tahu konsep, miskonsepsi dan karena ceroboh dalam mengerjakan. Tidak tahu konsep berarti siswa memang tidak memahami konsep dan tidak tahu konsep yang dipakai, sedangkan miskonsepsi merupakan gagasan yang tidak sesuai dengan pengertian ilmiah atau pengertian yang dicetuskan oleh para pakar serta bisa berupa pengertian yang tidak akurat terhadap konsep, penggunaan konsep yang salah, klasifikasi contoh-contoh yang salah, 
kekacauan konsep-konsep yang berbeda dan hubungan hierarkis konsep-konsep yang tidak benar.

Kesalahan-kesalahan yang dilakukan siswa saat menyelesaikan matematika tentunya mempunyai faktor penyebab tidak semata-mata karena ketidak fahaman siswa terhadap materi yang diajarkan melainkan ada faktor yang mempengaruhinya. Faktor penyebab siswa melakukan kesalahan bisa berasal dari luar (eksternal) ataupun dari dalam diri siswa (internal). Faktor dari dalam dapat berupa motivasi, kemampuan intelektual, minat, bakat, dan sebagainya. Faktor dari luar, dapat dipengaruhi oleh kondisi lingkungan, keluarga, teman, alat belajar, dan sebagainya (Irfan, 2017).

Kesalahan yang dilakukan siswa bisa juga dipengaruhi oleh kondisi psikologis siswa salah satunya kecemasan. Kecemasan siswa pada pelajaran matematika disebut kecemasan matematis (Mathematics Anxiety). Halgin \& Whitbourne, (2010) mengatakan kecemasan merupakan sikap yang berorientasi pada masa depan dan bersifat umum yang mengacu pada kondisi ketika individu merasakan kekhawatiran/kegelisahan, ketegangan, dan rasa tidak nyaman yang tidak terkendali mengenai kemungkinan akan terjadinya hal buruk. Cooke (2011) mengemukakan indikator kecemasan matematika terdiri dari 4 komponen yaitu mathematics knowledge/understanding, somatic, cognitive, dan attitude. Untuk mengetahui kesalahan-kesalahan yang dilakukan oleh siswa dapat menggunakan Newman Error Analysis (NEA).

Prosedur Newman adalah sebuah metode analisis kesalahan ketika memecahkan masalah (Jha, 2012). NEA sebagai alat untuk menemukan penyebab jenis kesalahan siswa dalam menyelesaikan masalah, yang dianggap oleh dunia dan telah diterapkan di berbagai belahan dunia seperti India, Malaysia, Thailand, Australia dan sebagainya (Junaedi, dkk, 2015).

Dalam analisis jawaban siswa menggunakan prosedur Newman Error Analysis terdapat 5 butir analisis Jenis kesalahan berdasarkan antara lain: 1) Kesalahan membaca (Reading error), kesalahan yang dibuat jika siswa tidak dapat membaca kata-kata kunci atau simbol yang tertulis pada masalah. 2) Kesalahan memahami (Comprehension error), siswa tidak dapat memahami kalimat soal. 3) Kesalahan transformasi (Transformation error), siswa tidak dapat mengidentifikasi operasi yang diperlukan untuk menyelesaikan masalah. 4) Kesalahan proses (Process skill error), siswa tidak tahu prosedur yang diperlukan untuk melakukan operasi secara akurat. 5) Kesalahan koding (Coding error), siswa menyelesaikan masalah dengan benar, tetapi tidak dapat menuliskan dalam bentuk notasi yang sesuai atau siswa mampu menyelesaikan masalah tetapi jawaban tidak sesuai dengan permintaan masalah (Friantini \& Winata, 2020).

Penelitian yang dilakukan oleh Rizki Nurhana Friantini dan Rahmat Winata pada tahun 2020 yang berjudul "Analisis Kesalahan Siswa Berdasarkan Newman Ditinjau Dari Tingkat Kecemasan Matematis”. Hasil penelitian ini menunjukkan bahwa siswa dari tingkat kecemasan matematis rendah menghasilkan kesalahan berupa kesalahan proses (process skills error) dan kesalahan koding (encoding error). Siswa dari tingkat kecemasan matematis sedang menghasilkan kesalahan berupa kesalahan transformasi (transformation error), kesalahan perhitungan (process skills error), dan kesalahan koding (encoding error). Siswa dari tingkat kecemasan matematis tinggi menghasilkan kesalahan berupa kesalahan memahami 
soal (comprehension error), kesalahan transformasi (transformation error). Dari hasil penelitian dapat disimpulkan bahwa semakin tinggi tingkat kecemasan matematis semakin banyak kesalahan yang dilakukan siswa.

Dari latar belakang diatas maka rumusan masalah dari penelitian ini adalah kesalahan-kesalahan apa saja yang dilakukan siswa SMA dalam menjawab soal berdasarkan Newman Error Analysis (NEA) ditinjau dari tingkat kecemasan matematis? dan Tujuan Penelitian ini adalah untuk mengetahui kesalahan-kesalahan jawaban yang dilakukan siswa SMA berdasarkan Newman Error Analysis (NEA) ditinjau dari tingkat kecemasan matematis.

\section{METODE PENELITIAN}

Penelitian ini merupakan penelitian kualitatif dengan jenis penelitian studi kasus (case study). Subjek dari penelitian ini adalah siswa kelas XI MIPA 1 sebanyak 5 siswa dengan tingkat kecemasan yang berbeda-beda yaitu siswa dengan tidak ada kecemasan, siswa dengan kecemasan rendah, siswa dengan kecemasan sedang, siswa dengan kecemasan berat, dan siswa dengan kecemasan berat sekali.

Mula-mula peneliti membagikan angket kecemasan kepada 29 siswa kelas XI MIPA1. Setelah itu, angket dianalisis dan diperoleh hasil tingkat kecemasan masingmasing siswa dan dipilih 5 siswa sebagai subjek penelitian. Pemilihan subjek dalam penelitian ini adalah dengan menggunakan teknik purposive sampling.

Prosedur penelitian yang dilakukan yaitu sebagai berikut: 1) menyusun angket kecemasan dengan 13 indikator kecemasan dan 30 butir pernyataan; 2) analisis hasil angket kecemasan dan mengkategorikn tingkat kecemasan menjadi 5 kategori yaitu tidak ada kecemasan, kecemasan rendah, kecemasan sedang, kecemasan berat dan kecemasan berat sekali; 3) dipilih 1 subjek dari masing-masing tingkat kecemasan; 4) diberikan soal tes sebanyak 4 soal; 5) wawancara; 6) analisis hasil kesalahan jawaban siswa menggunakan procedur Newman dan menarik kesimpulan.

Teknik analisis data yang digunakan adalah teknik data kualitatif model air (flow model) yang dikembangkan oleh Milles dan Huberman, 1992 (Zaidy \& Luthfianto, 2016) yang terdiri atas tiga tahapan antara lain: mereduksi data, menyajikan data, dan menarik kesimpulan.

\section{HASIL DAN PEMBAHASAN}

\section{Hasil Analisis Angket}

Berdasarkan hasil angket yang diberikan kepada kelas XI SMA Negeri Luragung dengan responden sebanyak 29 diperoleh hasil sebagai berikut:

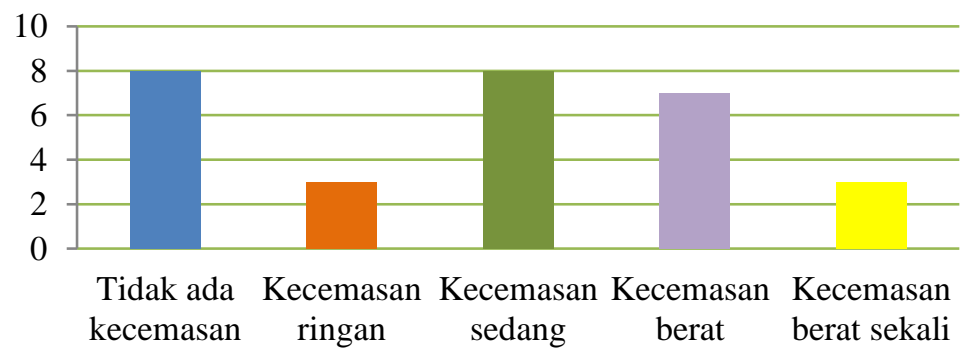

Gambar 1. Hasil angket kecemasan 
Dari Gambar 1 dapat dilihat bahwa siswa dengan tidak ada kecemasan sebanyak 8 siswa dengan skor akhir $<14$. Siswa dengan kecemasan ringan sebanyak 3 siswa dengan rentang skor $14-20$ skor. Siswa dengan kecemasan sedang sebanyak 8 siswa dengan rentang skor akhir $21-27$. Siswa dengan kecemasan berat sebanyak 7 siswa dengan rentang skor 28 - 41 dan siswa dengan kecemasan berat sekali sebanyak 3 siswa dengan rentang skor 42 - 56. Dari masing-masing tingkat kecemasan dipilih 1 subjek dari masing-masing tingkat kecemasan sehingga terdapat 5 subjek yang akan diteliti dan dianalisis hasil jawaban berdasarkan kesalahan Newman Error Analysis (NEA). Adapun subjek yang menjadi penelitian disajikan dalam Tabel 1 berikut ini.

Tabel 1. Subjek Penelitian
\begin{tabular}{|l|l|}
\hline Subjek & Tingkat Kecemasan \\
\hline Subjek 1 & Tidak ada kecemasan \\
\hline Subjek 2 & Kecemasan ringan \\
\hline Subjek 3 & Kecemasan sedang \\
\hline Subjek 4 & Kecemasan berat \\
\hline Subjek 5 & Kecemasan berat sekali \\
\hline
\end{tabular}

\section{Hasil analisis pekerjaan siswa}

Berikut hasil tes dan wawancara subjek penelitian untuk masing-masing tingkat kecemasan.

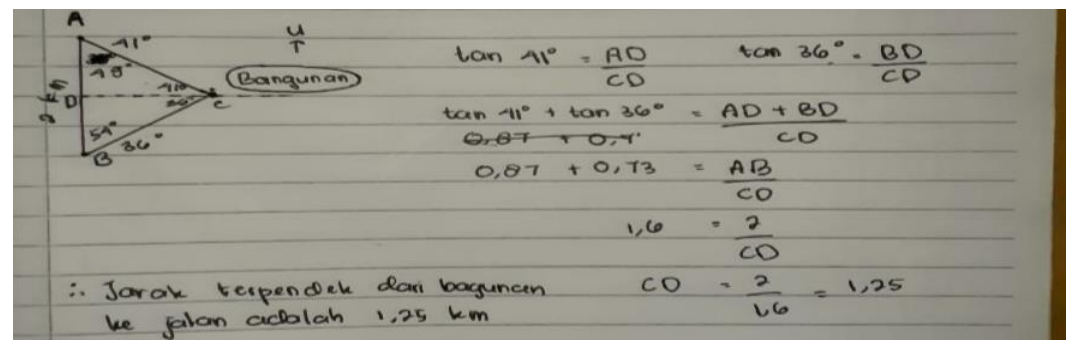

Gambar 2. Hasil Jawaban Subjek 1

Dari Gambar 2 dapat dilihat bahwa subjek 1 melakukan kesalahan memahami (comprehension error) yaitu siswa langsung menjawab soal tanpa menuliskan apa yang diketahui dan ditanyakan di soal. Secara keseluruhan proses dan perhitungan yang dilakukan siswa sudah baik hingga menemukan jawaban akhir yang diminta yaitu jarak terpendek bangunan ke jalan sebesar $1,25 \mathrm{~km}$. Ketika dilakukan wawancara, subjek 1 mengatakan bahwa subjek lupa untuk menuliskan apa yang diketahui dan ditanyakan dalam soal. 


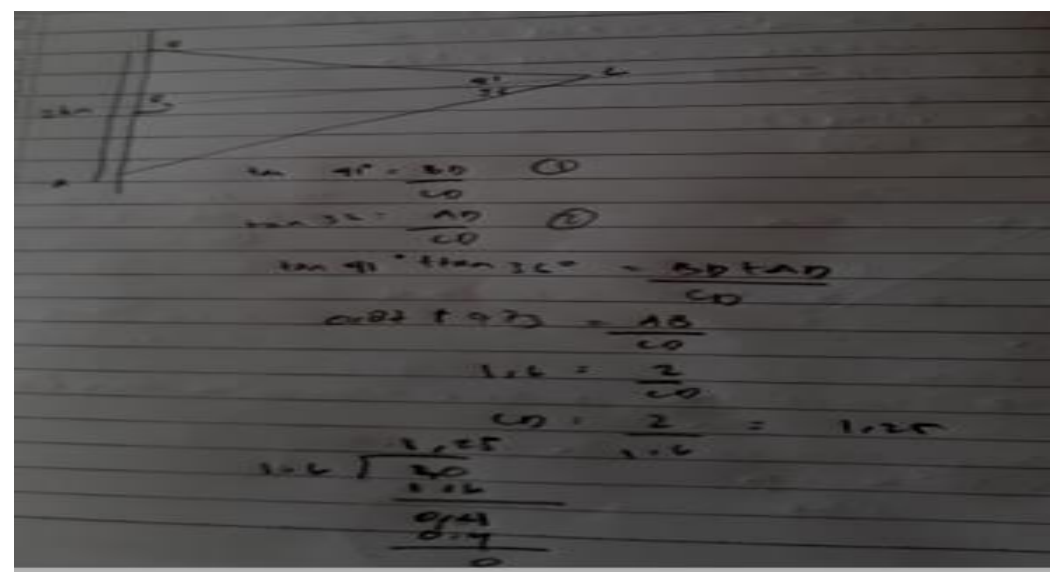

Gambar 3. Hasil Jawaban Subjek 2

Dari Gambar 3 dapat dilihat bahwa subjek 2 melakukan kesalahan memahami (comprehension error) dan kesalahan menuliskan jawaban akhir (encoding error). Kesalahan memahami (comprehension error) yang dilakukan yaitu siswa tidak menuliskan apa yang diketahui dan ditanyakan dalam soal, kemudian kesalahan menuliskan jawaban akhir (encoding error) yang dilakukan yaitu siswa tidak menuliskan kesimpulan pada jawaban akhir dan tidak menuliskan satuan yang diminta.

Ketika dilakukan wawancara, untuk kesalahan memahami (comprehension error) subjek 2 mengatakan bahwa karena sudah digambar ulang sehingga apa yang diketahui dan ditanyakan tidak dituliskan. Dan untuk kesalahan menuliskan jawaban akhir (encoding error) subjek mengatakan bahwa sudah jelas dijawaban akhir sudah tertera, jadi tidak menuliskan kesimpulan akhir.

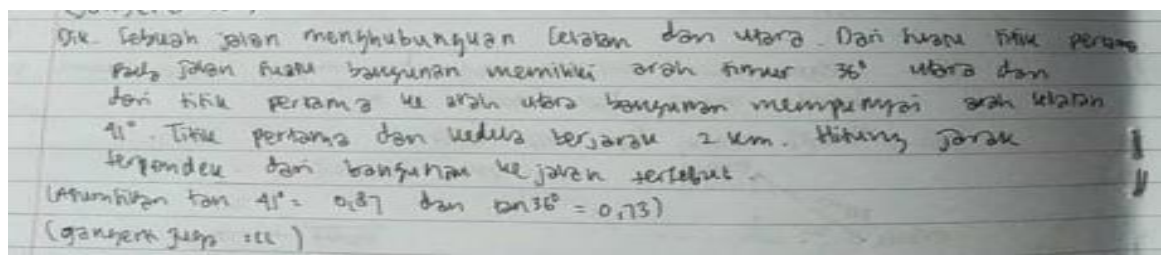

Gambar 4. Hasil Jawaban Subjek 3

Pada Gambar 4 subjek 3 tidak menjawab soal dan hanya menuliskan apa yang diketahui dan ditanyakan dalam soal dan subjek memberikan alasan mengapa tidak menjawab soal, yaitu dikarenakan tidak menegerti terhadapat soal tersebut. Pada saat wawancara subjek 3 menjawab bahwa kesulitan dalam mengerjakan soal tersebut karena subjek baru pertama kali menemukan soal yang seperti itu. 


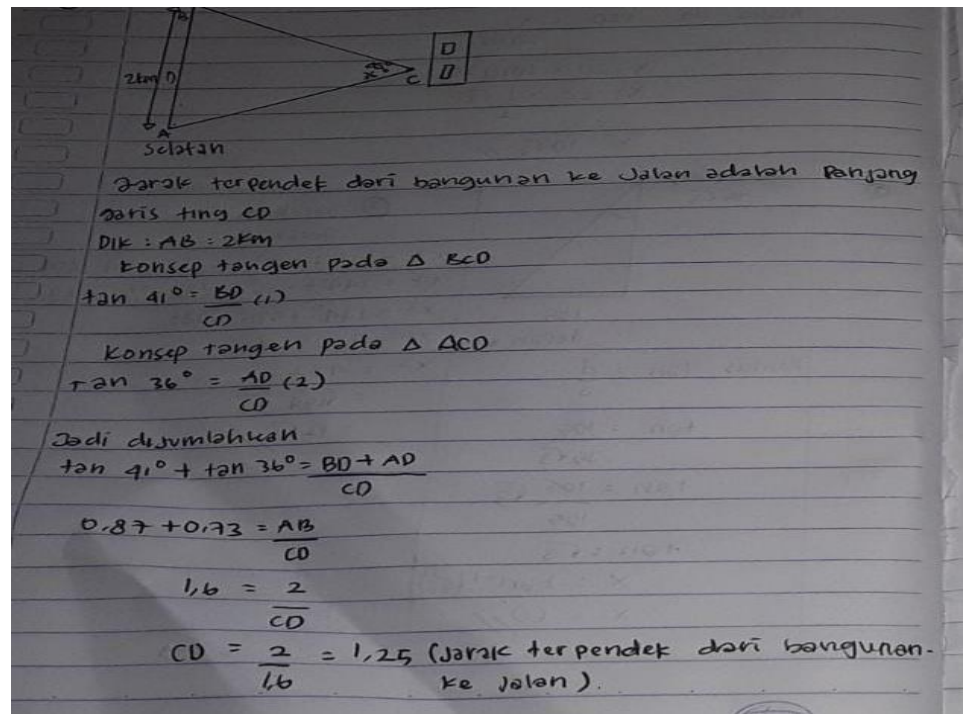

Gambar 5. Hasil Jawaban Subjek 4

Pada Gambar 5 dapat dilihat bahwa subjek 4 pada soal nomor 4 melakukan kesalahan menuliskan jawaban akhir (encoding) yaitu siswa tidak menuliskan satuan yang diminta dalam soal seharusnya siswa menuliskan satuan $\mathrm{km}$ terhadap jawaban akhirnya. Ketika dilakukan wawancara, subjek menjawab bahwa kesalahan tersebut dari dirinya sendiri karena buru-buru dalam mengerjakan soal dan kurang teliti sehingga tidak menuliskan satuan yang diminta dalam soal.

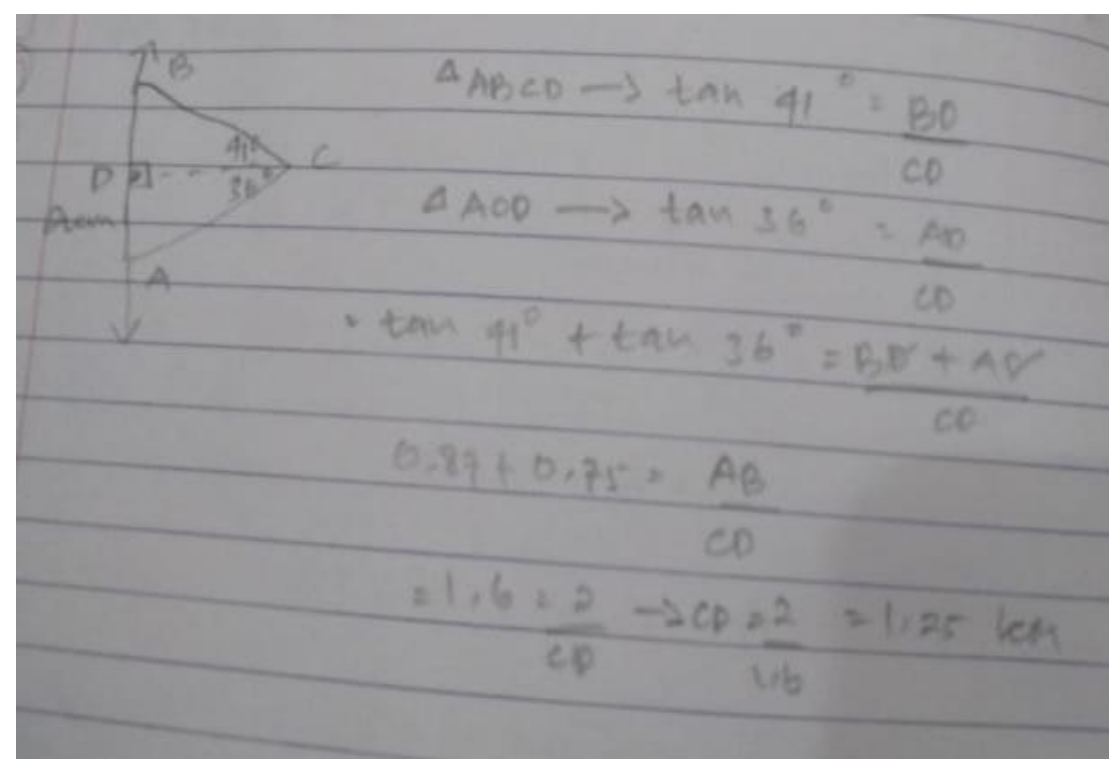

Gambar 6. Hasil Jawaban Subjek 5

Pada Gambar 6 dapat dilihat bahwa subjek 5 melakukan kesalahan membaca (reading error), kesalahan memahami (comprehension error), kesalahan tranformasi (transformation error), kesalahan ketrampilan proses (process skill error), dan kesalahan menuliskan jawaban akhir (encoding error). Pada kesalahan membaca (reading error) yaitu siswa mengilustrasikan soal kedalam gambar namun kurang tepat, dimana $2 \mathrm{~km}$ merupakan panjang $\mathrm{AD}$ ataukah panjang $\mathrm{AB}$, dan tidak ada 
keterangan lebih rinci mengenai gambar tersebut mana simbol untuk jalan, dan mana simbol untuk gedung. Pada kesalahan memahami (comprehension error) yaitu siswa tidak menuliskan apa yang diketahui dan ditanyakan dalam soal.

Pada kesalahan transformasi (transformation error) yaitu siswa menuliskan metode yang tidak tepat dalam menyelesaikan soal, untuk tan $41^{\circ}$ seharusnya untuk $\triangle \mathrm{BCD}$, bukan $\triangle \mathrm{ABCD}$.

Pada kesalahan kemampuan proses (process skill error) yaitu siswa tidak menjelaskan perhitungan dengan tepat, pada $\frac{B D+A D}{C D}$ siswa mengeliminasi huruf $\mathrm{D}$ untuk mendapatkan $\mathrm{AB}$, jelas proses tersebut keliru, jika mengeliminasi huruf seharusnya menjadi $\frac{B+A}{C}$ dan ini merupakan langkah yang salah, seharusnya siswa tidak perlu mengelimiasinya karena pada gambar yang diilustrasikan yaitu bahwa $\mathrm{AB}=\mathrm{BD}+\mathrm{AD}$, jadi siswa hanya perlu menuliskannya saja tanpa harus melakukan eliminasi. Selain itu kesalahan lain pada tahap ketrampilan proses yaitu kesalahan perhitungan yaitu $0.87+0.75$ seharusnya jawaban yang benar yaitu 1.62 namun siswa menjawab 1.6 saja. Hal ini tentu akan mempengaruhi perhitungan selanjutnya dan hasil akhir jawaban yang akan didapatkan. Pada kesalahan menuliskan jawaban akhir (encoding) yaitu siswa tidak menuliskan kesimpulan jawaban akhir. Ketika dilakukan wawancara, subjek menjawab bahwa subjek buru-buru dalam mengerjakan soal tersebut, dan subjek salah melihat nilai tan $36^{\circ}$. Dalam mengerjakan soal juga subjek mengerjakan soal sebisanya saja dan semampunya sehingga jawaban yang diminta kurang maksimal.

Secara keseluruhan berdasarkan hasil analisis dari 4 butir soal dan kelima subjek disajikan dalam Tabel 2 berikut ini.

Tabel 2. Jenis Kesalahan Siswa

\begin{tabular}{|c|c|c|c|c|c|}
\hline \multirow[t]{3}{*}{ Subjek } & \multirow{3}{*}{$\begin{array}{l}\text { Tingkatan } \\
\text { Kecemasan }\end{array}$} & \multicolumn{4}{|c|}{ Jenis kesalahan } \\
\hline & & \multicolumn{4}{|c|}{ Soal Nomor } \\
\hline & & 1 & 2 & 3 & 4 \\
\hline Subjek 1 & $\begin{array}{l}\text { Tidak ada } \\
\text { kecemasan }\end{array}$ & B & B & $\mathrm{B}, \mathrm{E}$ & B \\
\hline Subjek 2 & Kecemasan ringan & $\mathrm{B}, \mathrm{E}$ & $\mathrm{B}, \mathrm{E}$ & $\mathrm{B}, \mathrm{E}$ & $\mathrm{B}, \mathrm{E}$ \\
\hline Subjek 3 & Kecemasan sedang & $\mathrm{A}, \mathrm{C}, \mathrm{D}, \mathrm{E}$ & $\mathrm{E}$ & $\mathrm{N}$ & $\mathrm{N}$ \\
\hline Subjek 4 & Kecemasan berat & $\mathrm{B}, \mathrm{D}$ & $\mathrm{B}, \mathrm{E}$ & $\mathrm{B}, \mathrm{D}, \mathrm{E}$ & $\mathrm{E}$ \\
\hline Subjek 5 & $\begin{array}{l}\text { Kecemasan berat } \\
\text { sekali }\end{array}$ & $\mathrm{A}, \mathrm{B}, \mathrm{C}, \mathrm{D}, \mathrm{E}$ & $\mathrm{A}, \mathrm{B}, \mathrm{C}, \mathrm{D}$ & $\begin{array}{l}\text { A, B, C, } \\
\text { D, E }\end{array}$ & $\begin{array}{l}\text { A, B, C, } \\
\text { D, E }\end{array}$ \\
\hline
\end{tabular}

Catatan :

A : Kesalahan Membaca (reading errors)

B : Kesalahan Pemahaman (comprehension errors)

C : Kesalahan Transformasi (transformation errors)

D : Kesalahan Keterampilan Proses (process skill errors)

E : Kesalahan Penulisan Jawaban Akhir (encoding errors)

$\mathrm{N}$ : Soal Tidak Dikerjakan

Tabel 2 menunjukkan kesalahan yang dilakukan siswa berdasarkan subjek yang memiliki tingkat kecemasan yang berbeda-beda. Subjek 1 untuk soal nomor 1, 2, dan 4 melakukan kesalahan pemahaman (comprehension error), untuk soal nomor 
melakukan kesalahan pemahaman (comprehension error) dan kesalahan penulisan jawaban akhir (encoding error).

Subjek 2 untuk soal nomor 1, 2, 3, dan 4 melakukan kesalahan pemahaman (comprehension error) dan menuliskan jawaban akhir (encoding error). Subjek 3 untuk soal nomor 1 melakukan kesalalahan membaca (reading error), kesalahan transformasi (transformation error), kesalahan ketrampilan proses (process skill error), dan kesalahan penulisan jawaban akhir (encoding error). Untuk soal nomor 2 subjek hanya melakukan kesalahan penulisan jawaban akhir (encoding error). Dan untuk soal nomor 3 dan 4 subjek tidak menjawabnya.

Subjek 4 dengan tingkat kecemasan berat untuk soal nomor 1 kesalahan yang dilakukan yaitu kesalahan memahami (comprehension error) dan kesalahan ketrampilan proses (process skill error), untuk soal nomor 2 kesalahan yang dilakukan yaitu kesalahan memahami (comprehension error) dan kesalahan menuliskan jawaban akhir (encoding error). Untuk soal nomor 3 kesalahan yang dilakukan siswa yaitu kesalahan memahami (comprehension error), kesalahan ketrampilan process (process skill error), dan kesalahan menuliskan jawaban akhir (encoding error), untuk soal nomor 4 kesalahan yang dilakukan siswa yaitu kesalahan menuliskan jawaban akhir (encoding error).

Subjek 5 dengan tingkat kecemasan berat untuk soal nomor 1, 2, 3, dan 4 kesalahan yang dilakukan yaitu kesalahan membaca (reading error), kesalahan memahami (comprehension error), kesalahan transformasi (tranformation error), kesalahan ketrampilan proses (process skill error), dan kesalahan menuliskan jawaban akhir (encoding error). Subjek 5 melakukan semua kesalahan yang terdapat di Newman untuk setiap soal yang diberikan.

Dari hasil analisis didapatkan bahwa semakin tinggi tingkat kecemasan matematis semakin banyak kesalahan yang dilakukan siswa. Hal ini sejalan dengan penelitian yang relevan yang dilakukan oleh Friantini \& Wahinda (2020). Adapun hasil penelitian ini yang dilakukan Friantini \& Wahinda menunjukkan bahwa siswa dari tingkat kecemasan matematis rendah menghasilkan kesalahan berupa kesalahan proses (process skills error) dan kesalahan koding (encoding error). Siswa dari tingkat kecemasan matematis sedang menghasilkan kesalahan berupa kesalahan transformasi (transformation error), kesalahan perhitungan (process skills error), dan kesalahan koding (encoding error). Siswa dari tingkat kecemasan matematis tinggi menghasilkan kesalahan berupa kesalahan memahami soal (comprehension error), kesalahan transformasi (transformation error).

Ashcraft dan Faust (Zakaria \& Nordin, 2007) menyatakan bahwa kecemasan matematika yang tinggi akan mengakibatkan kemampuan berhitung yang rendah, pengetahuan yang kurang mengenai matematika, dan ketidakmampuan dalam menemukan strategi khusus dan hubungan dalam bidang matematika. Kecemasan matematika jelas merupakan hambatan bagi pencapaian matematika (Ashcraft \& Ridley 2005; National Mathematics Advisory Panel 2008; Lyons \& Beilock, 2011). Clute dan Hembree (Vahedi \& Farrokhi, 2011) menemukan bahwa peserta didik yang memiliki tingkat kecemasan matematika yang tinggi memiliki prestasi belajar matematika yang rendah. 


\section{KESIMPULAN}

Berdasarkan hasil dan pembahasan yang telah dipaparkan dapat disimpulkan bahwa siswa dengan tidak ada kecemasan matematis melakukan kesalahan memahami (comprehension error), dan kesalahan menuliskan jawaban akhir (encoding). Siswa dengan kecemasan matematis ringan melakukan kesalahan memahami (comprehension), dan kesalahan menuliskan jawaban akhir (encoding). Siswa dengan kecemasan matematis sedang melakukan kesalahan membaca (reading error), kesalahan transformasi (transformation error), kesalahan ketrampilan proses (process skill error), dan kesalahan menuliskan jawaban akhir (encoding). Siswa dengan kecemasan matematis berat melakukan kesalahan memahami (comprehension), kesalahan proses (process skill error), dan kesalahan menuliskan jawaban akhir (encoding). Siswa dengan kecemasan matematis berat sekali melakukan kesalahan membaca (reading error), kesalahan memahami (comprehension), kesalahan transformasi (transformation error), kesalahan ketrampilan proses (process skill error), dan kesalahan menuliskan jawaban akhir (encoding). Semakin tinggi kecemasan yang dialami oleh siswa, semakin banyak kesalahan yang dilakukan.

\section{DAFTAR PUSTAKA}

Ardiawan, Y. (2015). Analisis Kesalahan Mahasiswa dalam Menyelesaikan Soal Induksi Matematika di IKIP PGRI Pontianak. Jurnal Pendidikan Informatika dan Sains, 4(1), 147 - 163.

Cooke, A., Cavanagh, R., Hurst, C., \& Sparrow, L. (2011). Situasional effects of mathematics anxiety in pre-service teacher education. Makalah disajikan pada 2011 AARE International Research in Education Conference, Melbourne, Australia.

Friantini, N. R., \& Winata, R. (2020). Analisis kesalahan siswa berdasarkan newman ditinjau dari tingkat kecemasan matematis. Majamath: Jurnal Matematika dan Pendidikan Matematika, 3(1), 1-19.

Halgin, R. P. \& Whitbourne, S. K. (2010). Psikologi abnormal perspektif klinis pada gangguan psikologis. Jakarta: Salemba Humanika.

Irawan, E. (2012). Analisis Miskonsepsi Mahasiswa STKIP PGRI Pacitan pada Mata Kuliah Matematika Dasar Pokok Bahasan Logika Ditinjau Dari Gaya Kognitif Mahasiswa. Thesis: Tidak dipublikasikan

Irfan, M. (2017). Analisis kesalahan siswa dalam pemecahana masalah berdasarkan kecemasan belajar matematika. Jurnal Matematika Kreatif-Inovatif, 8(2), 143149.

Jha, K. S. (2012). Mathematics performance of primary school students in assam (india): an analysis using newman procedure. International Journal of Computer Applications in Engineering Sciences, 2(1), 17-21.

Junaedi, I.,Suyitno, A., Sugiharti, E., \& Eng, K. C. (2015). Disclosure Causes of Students Error in Resolving Disrete Mathematics Problems Based on NEA as A Means of Enhancing Creativity. International Jurnal of Education, 7(4), 31 -42 .

@ 2021 JagoMipa (https://jurnal.bimaberilmu.com/index.php/jagomipa) 
Kaliky, S. (2017). Meningkatkan Hasil Belajar Trigonometri Melalui Pembelajaran Kooperatif Tipe Think-Pair-Share (TPS) Siswa Kelas X1 SMA Muhammadiyah Ambon. Jurnal Matematika dan Pembelajaran, 5 (1), 68 - 86.

Lyons, M. I., \& Beilock, L. S. (2011). Mathematics anxiety: separating the math from the anxiety. Cerebral Cortex, 22(9), 2102-2110.

Mohyuddin, R. G., \& Khalil, U. (2016). Misconceptions of students in learning mathematics at primary level. Bulletin of Education and Research, 38(1), 133162.

Mulyono, A. (2009). Pendidikan Bagi Anak Berkesulitan Belajar. Jakarta: Rineka Cipta.

Siagian, D. M. (2016). Kemampuan Koneksi Matematika dalam Pembelajaran Matematika. MES : Journal of Mathematics Education dan Science, 2(1), 5867.

Vahedi, S., \& Farrokhi, F. (2011). A confirmatory factor analysis of the structure of abbreviated math anxiety scale. Iranian journal of psychiatry, 6(2), 47.

Zaidy, F., \& Luthfianto, M. (2016). Analisis Kesalahan Siswa SMK dalam Menyelesaikan Soal Program Linier Berdasarkan Newman's Error Analysis (Nea) Ditinjau Dari Kemampuan Matematika. Prosiding Seminar Nasional Pendidikan Matematika Ahmad Dahlan 2016. 297 - 303.

Zakaria, E., Nordin, N. M. (2008). The Effects Of Mathematics Anxiety On Matriculation Students As Related To Motivation and Achievement. Eurasia Journal of Mathematics, Science \& Technology Education, 4(1), 27-30. 